\title{
Democracia e república: o dissenso sobre a liberdade e as linguagens modernas da política
}

\author{
Marcelo Sevaybricker Moreira*
}

\begin{abstract}
Resumo
O presente trabalho discorre sobre a relação entre democracia e república. A análise inicia-se com o debate sobre conceito de liberdade no fim do século XX, caracterizado pelo avanço conservador do liberalismo e, como reação a ele, pela recuperação da tradição política do republicanismo. Distante de ser uma mera querela entre eruditos, a disputa entre essas linguagens fundantes da era moderna indica e constituiu um fator do debate em que se definem as funções do Estado e da democracia. A concepção de liberdade dos chamados neorrepublicanos, todos antagonistas, em maior ou menor grau, do liberalismo e proponentes de uma visão alternativa da liberdade é, então, avaliada. Embora o neorrepublicanismo não apresente uma concepção acabada de democracia, ele permite formular uma visão integradora dos seus principais problemas, tendo como norte a eliminação de todos os obstáculos à liberdade.

Neorrepublicanismo; Liberalismo; Democracia; Liberdade
\end{abstract}

\section{Introdução}

Este trabalho disserta sobre a complexa relação entre democracia e república. O que se pretende fazer é abordar o debate contemporâneo sobre a democracia a partir de uma polêmica que the é fundante no mundo moderno, a saber, a disputa sobre o significado da liberdade, opondo a tradição liberal de pensamento político à republicana.

De início, apresenta-se o contexto em que reemerge o debate sobre a liberdade no fim do século passado. Nele, ocorre um movimento duplo: de um lado o avanço de algumas variantes conservadoras do liberalismo contra as tradições socialistas e mesmo as vertentes do liberalismo igualitário, principalmente a da socialdemocracia; de outro lado, uma reação a esse avanço conservador, recuperando filosoficamente uma tradição "esquecida" na atualidade, o republicanismo. A disputa entre essas linguagens políticas, sobretudo a partir dos anos 1970, quando se verifica um "retorno" à Teoria Política (dada por alguns como "morta", nas décadas anteriores),

\footnotetext{
* Doutor em Ciência Política pela Universidade Federal de Minas Gerais (UFMG) e Professor Adjunto da Universidade Federal de Lavras (UFLA). Email: marcelomoreira@dch.ufla.br.
} 
indica e, ao mesmo tempo, constituiu historicamente um fator definidor do debate público em que se procurou estabelecer as funções do Estado e da democracia. Sobre isso, o trabalho avalia crítica e sinteticamente a "longa" história em torno ao conceito de liberdade "negativa", demonstrando como seu principal defensor, Isaiah Berlin, apropria-se de formulações anteriores sobre a liberdade, modificando-as, o que acabou por dificultar o debate sobre a mesma. Em seguida avalia-se a concepção de liberdade de alguns dos chamados neorrepublicanos: Maurizio Viroli, Quentin Skinner, Philip Pettit e Jean-Fabien Spitz. Ver-se-á que apesar de não haver um consenso entre eles, todos antagonistas, em maior ou menor grau, do liberalismo e proponentes de uma visão alternativa da liberdade, é possível estabelecer um conjunto de princípios comuns às suas formulações, compreendidas como variantes de uma mesma tradição de pensamento político, o republicanismo contemporâneo.

Espera-se identificar algumas contribuições, mas também alguns limites da concepção de democracia neorrepublicana. Embora não exista uma concepção acabada e homogênea dessa tradição, o republicanismo fornece uma linguagem importante para a compreensão alternativa de alguns dos problemas das democracias contemporâneas, tendo como norte a permanente superação dos obstáculos à realização da liberdade.

\section{$O$ debate entre liberais e neorrepublicanos no fim do século $X X$}

James Hankins, em recente balanço dos estudos em torno ao republicanismo (2003), teve o mérito de identificar três momentos importantes desse "movimento" na contemporaneidade. O primeiro deles é constituído pela publicação, em 1955 , do estudo seminal de Hans Baron, The crisis of Early Italian Renaissance. Com ele, os estudiosos voltaram seu interesse para a existência de uma tradição intelectual chamada por Baron de "humanismo cívico", forjada principalmente em algumas repúblicas italianas durante o Renascimento que, retomando traços da cultura grecoromana, sublinhava a importância dos ideais de patriotismo, de governo popular e de 
devoção ao serviço público. A obra de Baron consiste numa polêmica com outro texto célebre sobre o período, A civilização do Renascimento na Itália, de Jacob Burckhardt, que asseverava como principal legado dessa tradição para a Modernidade a configuração do indivíduo. "Esse homem-artista, individualista ao extremo, certo de suas potencialidades e de sua capacidade para forjar a sua própria vida, representava, para o escritor suíço, o protótipo do que viria a ser o homem moderno" (Bignotto, 2001, p. 18). Contra essa interpretação, Baron caracterizou a Renascença não como:

\footnotetext{
O momento de consolidação dos regimes monárquicos ou tirânicos, nos quais o homem encontrou sua própria individualidade, mas sim a época do surgimento de uma vida política rica, centrada em valores próximos aos que haviam estado no centro da existência das cidades livres do passado (idem, ibidem, p. 18).
}

Duas décadas após Baron delimitar o "humanismo cívico", o livro The Maquiavellian moment, de John Pocock, argumentava que essa tradição, chamada por ele de "republicanismo clássico", constituiu na história das ideias políticas da modernidade uma forma de linguagem própria (centrada nos ideais expostos por Baron), retraduzidos criticamente por Maquiavel, e que, depois de serem obscurecidas pela hegemonia do pensamento político contratualista anglo-saxão, reapareceria nos discursos dos defensores do Parlamento inglês contra a monarquia absoluta de Carlos I. Esse segundo marco no republican turn, mais do que somente ter sido capaz de encontrar tópicas republicanas nos discursos dos ingleses durante a Revolução Gloriosa, conseguiu reconstruir o processo pelo qual as ideias republicanas "atravessaram" o Atlântico, sendo incorporadas pelos defensores da independência das treze colônias britânicas na América, produzindo o que Pocock chamou de "história túnel". Contra uma interpretação canônica da história dos Estados Unidos, segundo a qual seus pais-fundadores teriam sido fundamentalmente influenciados pelo pensamento de John Locke, Pocock revela que os mesmos ideais republicanos forjados no Renascimento italiano, recuperados pelos ingleses do século XVI-XVII, foram armas discursivas decisivas nas mãos de pensadores como Thomas Paine, Thomas Jefferson, Benjamin Franklin, entre outros, que, para contestar o domínio britânico, se voltaram aos princípios do humanismo cívico e da república romana, ainda que tivessem que adaptá-los às condições específicas das treze colônias. 
Um terceiro momento de redescoberta dessa herança intelectual se deu com a obra de Quentin Skinner, As fundações do pensamento político moderno. Contestando parcialmente a tese de Baron acerca da inventividade dos humanistas cívicos e da singularidade de Florença (Skinner, 1990, p. 122), esse autor identificou alguns desses ideais republicanos no pensamento medieval escolástico e na tradição da retórica antes do Renascimento. Apesar dessa ressalva que "produzia um deslocamento cronológico relativamente às origens, retrocedendo no tempo e inserindo os humanistas e Maquiavel numa linha de continuidade que viria da Idade Média até a modernidade" (Pancera, 2010, p. 29), o historiador de Cambridge reafirmava a importância da tradição republicana na gênese do mundo moderno, isto é, no debate sobre a constituição do Estado-nação que, além da via das monarquias absolutas, poderiam adotar a solução republicana, solução viável e a única capaz a garantir a existência da liberdade. A despeito dos estudos de revisionismo histórico sobre o republicanismo (suscitados por essas três obras acima citadas) terem modificado em alguns aspectos a visão sobre o "humanismo cívico" ou "republicanismo clássico", avalia-se que eles não conseguiram abalar as bases do modelo baroniano, atestando, ao mesmo tempo, o avanço diminuto da historiografia sobre esse período (Hankins, 2003), mas também a solidez desse modelo.

Iseult Honahan, avaliando também o republican revival, diferencia três linhas de debate nessa área. Diferentemente de Hankins, o trabalho de Honahan indica que o impacto desse "movimento" foi mais amplo do que ter proporcionado uma nova visão sobre a história. Além da linha detectada por Hankins, constituiu-se sob a denominação de constitucionalismo uma segunda seara de debates. Particularmente nos Estados Unidos, o ideário republicano tem sido evocado para contestar a visão tradicional sobre a constituição, entendida como limite legal ao poder, e compreendêla como um exercício contínuo e histórico de autogoverno, baseado menos nos interesses particulares e mais no bem comum. Um terceiro campo seria o da teoria política normativa. Têm-se, argumenta a autora, recuperado algumas ideias 
republicanas a fim de pensar problemas precípuos da política contemporânea, a partir das noções de comunidade, de liberdade e de participação política.

Se o texto de Hankins e o de Honahan permite vislumbrar a amplitude e complexidade do republican revival, eles não explicitam, no entanto, que todo esse esforço intelectual de recuperação da tradição do republicanismo respondeu, em grande medida, a uma revisão anterior do liberalismo. Esse revisionismo liberal consistiu na formação de diversas tendências conservadoras que, por sua vez, reagiam contra a expansão na primeira metade do século XX do liberalismo igualitário e contra as tradições socialistas, sobretudo, em relação à experiência do comunismo soviético.

Deu-se relevo aqui aos diversos momentos do debate intelectual no século $X X$ ocorrido no mundo anglo-saxão. Isso não significa que fora deste, o ideal de liberdade não estivesse sendo debatida. Apenas como exemplo, cumpre lembrar a obra do filósofo francês Claude Lefort que, desde os anos 1970, se volta ao tema do republicanismo. Oriundo de uma vertente marxista heterodoxa, Lefort vai aos poucos aproximando seu horizonte de reflexão da tradição republicana. Nesse sentido, seu trabalho sobre Maquiavel teve o mérito de destacar o elogio do florentino à república e, mais, às repúblicas abertas à participação popular. Diferentemente das leituras republicanas do pensamento de Maquiavel que se concentravam nos Discursos sobre a Primeira Década de Tito Lívio dando pouca importância para O príncipe (e que, portanto, eram acusadas de serem parciais), Lefort foi capaz de identificar um conjunto de pressupostos relativos à natureza da política que confere unidade à obra do secretário florentino, como um todo (Pancera, 2010, p. 33-35). Essa unidade consiste no pressuposto de que a política é inevitavelmente o espaço do dissenso e do conflito, ou dizendo de outro modo, os inevitáveis humores dos homens que cindem ao meio o corpo político: o desejo de domínio dos "grandes" e o desejo, assimétrico, de não opressão do povo.

É preciso ter clareza que ao operar com o conceito de "tradições intelectuais" está se atribuindo a esses autores uma classificação ex post, que não estava, necessariamente, consciente neles. A tradição é cultivada e construída por quem deseja compreender o modo como o passado "informa" o presente, não se confundindo com o primeiro. Mais do que mero rótulo, a ideia de tradição contribui para organizar o campo da Teoria Política, considerando os diálogos, apropriações e 
polêmicas entre os diversos autores. O cientista político Mark Bevir diz que, para iniciar a interpretação de um texto, é necessário postular a existência de tradições não como essências fixas e uniformes, mas como conjunto de crenças e valores herdados em transformação no tempo.

\begin{abstract}
A tradição fornece apenas um ponto de partida que nos permite explicar por que as pessoas abraçaram determinadas crenças. Não fornecem um contexto que aumente a nossa compreensão das crenças das pessoas. (...) Uma das propriedades comuns a todas as tradições é que, embora os indivíduos comecem com elas, eles não se limitam aos modos por que os indivíduos poderiam desenvolvê-las. (...) Eis por que as tradições não bastam para explicar por que alguém adotou determinada rede de crenças. Os indivíduos podem estender, modificar e até mesmo rejeitar as tradições que herdaram (2008, p. 276).
\end{abstract}

A tradição fornece um pano de fundo que permite a compreensão das crenças de um autor, mas não é critério suficiente, pois em cada obra ligada a ela é possível identificar pontos de discordância. Considerar que dois ou mais autores se inserem em uma tradição de pensamento, não implica homogeneizar os seus pensamentos, mas inseri-los inicialmente num mapa mais geral de entendimento que, todavia, requer uma análise detida da obra de cada um deles, atentando para suas divergências e concordâncias.

Destarte, compreende-se a crítica de autores como, por exemplo, Jeremy Waldron (2012, p.103-104) a um certo uso da ideia de uma tradição liberal, excessivo e demasiado simplificador. Com alguma frequência, o uso dos termos "liberal", "conservador", "republicano", etc., atende mais aos interesses ideológicos do que o de precisão analítica. No entanto, como o mesmo autor reconhece e faz uso, tal recurso heurístico é fundamental na organização do debate político. Ao que parece, o decisivo é ser capaz de nuançar as "grandes" tradições intelectuais através do reconhecimento das peculiaridades, diferenças e abordagens em cada um dos autores, e não propriamente abandonar esse recurso.

Assim, quando se fala em tradição liberal, opera-se com uma pluralidade de linguagens, mas, ao mesmo tempo, com uma unidade, construída a partir do 
compartilhamento de certos princípios. Roberto Guerra observa, nesse sentido, que todo liberalismo (do "igualitário radical" ao "conservador proprietarista") comunga dos seguintes princípios, mobilizando-os de modo diferenciado: 1) uma concepção individualista frente a toda perspectiva coletivista, entendendo o indivíduo como um ser autossuficiente, pré-político, portador direitos e liberdades que lhes são inerentes; 2) em concordância com o princípio acima exposto, a submissão da política e do Estado às leis gerais que servem ao desenvolvimento dos indivíduos; 3 ) isso implica a primazia das leis sobre os homens; 4) a assunção da divisão e equilíbrio entre os poderes a fim de se evitar o abuso de poder; 5) a preferência da democracia representativa como meio mais adequado para garantir os princípios anteriores ${ }^{1}$.

O liberalismo conservador, como foi dito, surgiu como contestação das linguagens liberais que incorporam topicamente algumas reivindicações das tradições socialistas, como a diminuição das desigualdades sociais, a legislação trabalhista e a extensão dos direitos políticos a outros grupos, ainda que não abdiquem dos princípios liberais acima descritos. Basicamente, o liberalismo igualitário, dando prioridade à liberdade do indivíduo, assume a ideia de que é possível maximizar as diferentes liberdades individuais. Para garantir isso, esses liberais pressupõe uma tendência à crescente harmonização entre os indivíduos que, em função do seu aprimoramento moral, dissolveria os conflitos potenciais entre eles. Eles assumem, em resumo, sete princípios: 1) a limitação parcial do direito de propriedade; 2) o reconhecimento de algum grau de liberdade positiva; 3) a igualdade da lei ante a igualdade de oportunidades; 4) uma maior redistribuição da riqueza; 5) a interferência limitada do Estado a fim de promover o bem-estar; 6) a democracia representativa; 7) e a expansão da participação política aos cidadãos (Guerra, 1998, p. 55). Um liberal igualitário que exerceu considerável influência no período do pós-guerra foi precisamente John Maynard Keynes, que defendeu que o liberalismo deveria se desprender das concepções individualistas e do laissez-faire, fazendo com que o Estado intervisse na vida social a fim de promover a manutenção do capitalismo, mas também a justiça social e a liberdade individual. Mais recentemente, pode-se evocar a obra de John Rawls como expoente dessa variante liberal (Vita, 2011).

1 A preferência liberal pela democracia, aludida por Guerra, é, na realidade, algo recente, historicamente, se constituindo principalmente após o lluminismo. 
Posteriormente a essas tradições igualitárias do liberalismo, que se enraízam na cultura política ocidental de forma exemplar na cultura e prática política do Estado de Bem-estar social, surgem, pensadores que procuram revisar o liberalismo a fim de, supostamente, recuperar o autêntico espírito do liberalismo clássico, sem, contudo, incorrer nos equívocos dos igualitários. Trata-se do liberalismo conservador contemporâneo, classificado por Guerra segundo três linhagens: o neoliberalismo (sobretudo Friedrich Hayek e Milton Friedman), o neoconservadorismo (como Robert Nisbet) e o libertarianismo (tais como, Robert Nozick e Murray Rothbard). Apesar das diferenças internas, essas correntes comungam, por sua vez, de seis ideias básicas: 1) o direito absoluto à propriedade privada; 2) a defesa do capitalismo como forma mais eficiente e justa de organização da economia; 3) a limitação drástica da intervenção estatal a funções essenciais, como a proteção à propriedade individual e aos contratos particulares; 4) a igualdade entendida exclusivamente como igualdade perante a lei; 5) a democracia entendida como disputa não violenta pelo poder entre elites e endossada, apenas por meio do voto, pelo povo; 6) e a liberdade compreendida precípua ou exclusivamente negativa, isto é, como gozo individual de direitos e da privacidade.

Percebe-se que no centro dessa polêmica está novamente o conceito de liberdade, assumido como bandeira política do movimento liberal conservador, mas compreendido como conceito negativo, e completamente dissociado das ideias de igualdade de oportunidades, de justiça social, de autogoverno, que alguns liberais igualitários reconheciam como legítimas (Guerra, 1998, p. 233). Numa perspectiva claramente elitista, de redução radical do princípio da soberania popular, em que as "massas" são associadas à apatia (naturalizada pelos autores) e à irracionalidade (fruto de seu suposto infantilismo político), os liberais conservadores se assumem como defensores de uma liberdade que se forma privadamente e em antagonismo com o Estado, por oposição às tradições que dão primazia à política e tornam o Estado onipotente. Para os liberais-conservadores importa reduzir ao máximo o peso do 
Estado e da democracia e aumentar o espaço de atuação do mercado (Guerra, 1998, p. 244).

É importante salientar que na tradição liberal, como um todo, a política não é compreendida como meio de realização da individualidade e da liberdade humana; essas precedem a primeira e, ainda que a política sirva para salvaguardar os direitos dos indivíduos, constitui, ao mesmo tempo, uma ameaça permanente a eles. 0 republicanismo apresenta uma visão antagônica à liberal, em que Estado e a lei não se contrapõem à liberdade pessoal, mas são garantias dela. Nesse sentido, pode-se compreender o neorrepublicanismo como um movimento de revalorização da política e da esfera pública. Ele emerge no debate acadêmico rechaçando, assim, tanto o liberalismo conservador, quanto à ortodoxia comunista que condiz com a supressão da liberdade.

\section{O conceito de liberdade negativa e a tradição liberal}

Deve-se também lembrar que o conceito de liberdade negativa que é incorporado pelo liberalismo conservador foi estabelecido de modo paradigmático por Isaiah Berlin no controvertido texto Quatro ensaios sobre a liberdade, o ensaio mais influente da teoria política contemporânea (Skinner, 2005, p. 20). Nele, Berlin lança mão de uma argumentação convincente que assevera que a única liberdade possível e desejável no mundo moderno é a liberdade negativa, isto é, "a ausência de obstáculos que impedem minhas decisões reais, senão também ausência de obstáculos que impedem minhas decisões possíveis, para agir de determinada maneira, se é isso o que quero" (Berlin, 1981, p. 144). A liberdade positiva, por seu turno, é definida como ser senhor de si, ter autodomínio, participar ativamente do governo e dos assuntos públicos.

Além de encarcerar o debate sobre a liberdade em apenas duas opções (liberdade negativa versus positiva), simplificando-o demasiadamente (Bignotto, 2003, p.239), Berlin assevera que a concepção de liberdade positiva, além teoricamente equivocada (confundindo liberdade com reconhecimento social, igualdade ou justiça), é politicamente perigosa. Supor que a liberdade seja uma realização do indivíduo racional na vida pública, implica admitir a necessidade de perseguir os mesmos fins 
racionais para toda a coletividade ("bem comum"); ora, essa harmonia estabelecida por leis racionais e universais, conclui Berlin, redunda em formas de governo que suprimem a pluralidade dos modos de vidas, cerceando a liberdade negativa. Da liberdade positiva, associada à participação política do cidadão, Berlin infere, então, o despotismo.

Não se deve ter dúvida quanto ao caráter fortemente ideológico do texto de Berlin, publicado originalmente em 1969 (Pettit, 1998, cap. 1; Skinner, 2005, p. 48). No contexto da Guerra Fria, de franca disputa entre capitalismo e comunismo, Berlin esposa assumidamente uma posição que associa liberdade positiva às tradições socialistas e estas a fórmulas autoritárias de governo. Como nota Guerra, a concepção de liberdade negativa está relaciona da à defesa do sistema econômico de livre mercado, da distinção rígida entre o público e o privado (limitando o primeiro e ampliando o segundo), de uma concepção também negativa do Estado (que teria como função unicamente a proteção da vida e da propriedade). Para Berlin, o que seria desejável é que as leis procurassem definir um espaço máximo e inviolável da vida individual para que se pudesse gozar privativamente de sua liberdade, abandonando qualquer aspiração de promover justiça social, diminuição das desigualdades, ou de reconhecimento dos indivíduos marginalizados, opinião com a qual concordam os diversos liberais conservadores do século XX.

Na realidade, alguns desses radicalizam ainda mais a concepção liberdade de Berlin. O libertarianista radical Rothbard, por exemplo, criticando as concessões de Hayek à intervenção do Estado em situações excepcionais e partindo de uma noção de liberdade como propriedade, chega à formulação polêmica de que uma mãe tem o direito de abortar o "invasor indesejado do seu corpo" (sua propriedade), bem como os pais que, apesar de não poderem violentar seus filhos (pois, nesse caso, violaria a liberdade deles), têm pleno direito de deixá-los morrer de fome, frio ou de doença, "posto que nada pode forçá-los a isso" (Guerra, 1998, p. 135).

O conceito de liberdade negativa de Berlin, todavia, para ser bem compreendido, inclusive com sua "antropologia do homem egoísta" (Bignotto, 2003, p. 
45), deve ser remetido a uma tradição intelectual mais antiga a qual ele pertence. Formulado inicialmente por Jeremy Bentham, o conceito de "liberdade negativa" significa a ausência de lei e de impedimento para minha vontade irrestrita. O filósofo utilitarista, ferrenho crítico da Revolução Francesa e da Independência e da Revolução americanas, declarava que as leis não servem para a manutenção da liberdade, produzindo sua redução (Pettit, 1998, p. 43-45). Liberdade, resume Bentham, é "ausência de coerção".

Embora não seja o caso de recompor toda essa complexa linhagem intelectual que se forma desde o século XVII, importa relembrar alguns de seus momentos mais importantes, inclusive que Bentham cria o conceito negativo de liberdade a partir da obra de Hobbes. É na filosofia desse pensador seiscentista, portanto (que dificilmente pode ser entendido como um "liberal" stricto senso, haja vista sua defesa da soberania absoluta e indivisa do Estado), que se encontra o núcleo fundante da concepção de liberdade negativa. Hobbes contestou sistematicamente a tradição republicana, influente na Inglaterra revolucionária do século XVII, que associava liberdade a um governo em que os cidadãos participam dos assuntos públicos: "Hobbes é o mais formidável inimigo da teoria republicana da liberdade, e seus esforços para desacreditá-la constituem um momento que faz época na história do pensamento político de língua inglesa" (Skinner, 2010, p. 13). Levando em conta que, para os republicanos, o homem livre é o antípoda do escravo, ou seja, aquele que vive sob o arbítrio e domínio de outrem, "Hobbes nega que o simples fato de viver numa dependência da vontade de outrem desempenharia algum papel na limitação da liberdade do homem livre" (Idem, ibidem, p. 147). Para ele, "a palavra liberdade significa propriamente ausência de oposição" (Idem, ibidem, p. 193). Somente, portanto, quando há uma oposição ou interferência é que a liberdade sofre restrição, independentemente da forma de governo, da participação na vida pública, etc. Todo governo soberano restringe necessariamente a liberdade, pois impõem leis, assegura Hobbes, confrontando diretamente a concepção republicana que afirmava que a liberdade só é possível em um regime soberano no qual "todos os cidadãos dão seu consentimento ativo às leis que todos obrigam" (Idem, ibidem, p. 75). Por essa razão, apresenta a polêmica tese de que a liberdade independe da forma de governo, sendo a mesma numa república e num governo despótico: "não há diferença, ele [Hobbes] 
insiste, entre liberdade sob o popolo em Lucca e a liberdade sob o sultão em Constantinopla" (Idem, ibidem, p. 153).

Pode-se também, mapeando as continuidades intelectuais dessa concepção de liberdade como não-interferência, como expressa por Hobbes, e como liberdade negativa, como definida por Bentham e Berlin, identificar seus desdobramentos na obra de dois autores influentes na tradição liberal, Benjamin Constant e Montesquieu.

$\mathrm{Na}$ palestra $A$ liberdade dos antigos comparada à dos modernos, Constant condena os excessos dos revolucionários franceses que, em prol de se promover a liberdade como autogoverno, coibiram em seu país a liberdade individual. O autor acredita que a liberdade como participação no governo só é possível na Antiguidade; no caso dos países modernos, a única liberdade possível é a individual, experimentada em regimes representativos. Contraposta à liberdade dos antigos (entendida como participação ativa no governo), a liberdade no mundo moderno é algo que se realiza "fora" do Estado, na esfera privada, ainda que, como confessa Constant, seja preciso um mínimo de participação na escolha e vigília dos governantes para que essa liberdade moderna não seja sacrificada pelo uso privatista que possa se fazer do poder político.

Assim, Constant formula um argumento que se constituiria doravante em um dogma liberal, a saber, a incompatibilidade entre a vida moderna e a participação política ativa dos cidadãos². Como nota Bignotto (2003), a apatia política dos cidadãos modernos é, nessa chave de entendimento, naturalizada. Todavia, se os indivíduos nos tempos atuais são caracterizados como alheios à vida pública e unicamente interessados em sua satisfação pessoal, cabe perguntar por que ele entende que os indivíduos sejam capazes de controlar os representantes, pergunta que Constant sequer se faz. Ou seja: será que a liberdade política nos governos representativos é condição suficiente para a garantia da autonomia do indivíduo? Essa indagação não

\footnotetext{
${ }^{2}$ Essa tópica comparece com frequência nas diversas tradições da moderna ciência política, desde o elitismo democrático, o pluralismo democrático e a teoria da escolha racional (Pateman, 1992).
} 
pode ser respondida de modo satisfatório a partir da abordagem desse autor nem tampouco por Berlin.

Outras ponderações sobre o texto de Constant são necessárias. Em primeiro lugar, deve-se destacar que ao diferenciar a liberdade dos antigos da dos modernos, 0 autor procura criticar o legado da Revolução Francesa, na medida em que ao invés de recuperar um modo de vida próprio dos antigos, levou-os à barbárie. Um segundo ponto é que, para ele, a Modernidade está apartada da Antiguidade e não se deve procurar resgatar essa herança. Como observa Bignotto, o argumento de Constant da incompatibilidade entre as duas formas de liberdade só é válido se assumirmos a premissa de que os tempos atuais são outros e que caminhamos "inexoravelmente para um abandono progressivo do passado em favor de uma nova ordenação social" (Bignotto, 2003, p. 40). Baseando-se numa noção linear e progressiva do tempo (e rechaçando a concepção cíclica do tempo, ainda comum no século XVIII), Constant constrói todo o seu argumento: "sem a noção de progresso não é possível afirmar que os antigos foram deixados para trás de forma definitiva" (idem, ibidem, p. 41).

A tópica de que a liberdade dos antigos é incompatível com os tempos modernos é, por sua vez, uma clara retomada da tipologia de governos feita por Montesquieu, distinguindo a república, a monarquia e o despotismo segundo o espírito dominante em cada um desses regimes ${ }^{3}$. Todavia, acrescenta Montesquieu, no mundo moderno, marcado pelo comércio, as repúblicas tornam-se difíceis, na medida em que o sentimento de solidariedade, essencial para o exercício da virtude pública, torna-se escasso. Nesse contexto, a liberdade política não significa participação na política, mas precipuamente segurança contra um ataque ou punição arbitrária. Embora reconheça a atração exercida pela liberdade política, segundo Honahan, Montesquieu asseguraria que a liberdade plena não é mais factível na modernidade; a garantia da liberdade residiria não mais na virtude dos cidadãos, mas no controle mútuo e separação dos poderes.

\footnotetext{
${ }^{3}$ Esse filósofo distinguia três tipos de regime político, classificados de acordo com o número dos que governam e do "espírito" que predomina em cada um deles. As repúblicas (que podem ser aristocráticas ou democráticas) são governos em que o povo, ou parte dele, governa e seu espírito é a virtude. A monarquia é o governo de um só, agindo de acordo com a lei, e nela prevalece o sentimento de honra. O despotismo é o governo de um só, de acordo com sua própria vontade, no qual impera o medo.
} 
Contudo, por mais canônica que seja essa interpretação da obra de Montesquieu, repetida aqui por Honahan, ela não é isenta de problemas. Como bem observa Bignotto, Montesquieu foi decisivo tanto na formação do republicanismo na França e nos Estados Unidos, quanto para os críticos dessa tradição que nem sempre utilizaram de modo adequado os seus argumentos. Embora confessasse sua preferência monárquica, o filósofo iluminista contribuiu para que se reivindicasse no contexto em antecedeu a Revolução Francesa limites ao poder real, independência dos parlamentos e respeito à diversidade religiosa. Por muito tempo, o nome de Montesquieu, bem como o de Rousseau, se incorporou, portanto, à linguagem do republicanismo francês. Por outro lado, as suas ideias relativas ao tamanho dos Estados e a associação entre virtude cívica e república e entre primeira e o mundo antigo, contribuíram para consolidar a tópica de que a república é algo impossível de se realizar.

A ideia de que as repúblicas necessitam de que os Estados sejam criados em territórios pequenos é usualmente entendida como condição suficiente de impossibilidade das repúblicas. Mas os próprios norte-americanos, inspirados em Montesquieu, criaram uma solução institucional para esse problema: a federação de repúblicas. Assim, se territórios extensos e grandes populações criam dificuldades para a convivência próxima entre os indivíduos, não tornam o governo republicano uma quimera.

O segundo topos, mais complexo que o primeiro, diz respeito à vinculação entre república e sua paixão correspondente, a virtude cívica, e entre essa e a Antiguidade. Em primeiro lugar, o fato de a virtude ser a "motor" do governo republicano, não significa que ela seja exclusiva dessa forma de governo ou que a república se baseie tão somente na virtude de seus cidadãos. O próprio Montesquieu assevera que a virtude é também necessária na monarquia, para refrear os ímpetos da nobreza. Ademais, a Roma republicana, admirada e analisada por ele, logrou sucesso não apenas por causa da virtude dos romanos, do seu amor pela liberdade e de seu ódio pela opressão, mas pelas instituições que, com um sistema de contrapesos, soube 
coibir os abusos de poder. Segundo: em geral, os intérpretes tenderam a compreender a noção de virtude como sinônimo de heroísmo, o sacrifício pessoal do cidadão pela sua pátria. Mas Montesquieu considera a virtude como um sentimento e não como um imperativo racional, caracterizado como "submissão às leis, obediência às regras de conduta, frugalidade e uso consciente de recursos públicos" (Bignotto, 2010, p. 42), associando-a ao amor pela igualdade. A virtude cívica serve, portanto, antes como um "ideal regulador" da ação humana a ser fomentado pela educação dos cidadãos.

Como vimos, os autores liberais, Constant e Berlin, associaram as ideias de Montesquieu sobre a virtude republicana à repressão, seu suposto corolário se fosse buscada no mundo moderno. O raciocínio é aparentemente simples: se as repúblicas necessitam da virtude para serem regimes perfeitos, é necessário forçar os indivíduos à virtude. Obviamente que os críticos liberais supracitados têm em vista as revoluções, particularmente a Francesa que degenerou no Terror, suprimindo a liberdade em nome da virtude. Todavia, como comenta Bignotto, eles não apresentam nenhuma evidência de porque, baseando-se em Montesquieu, qualquer ação virtuosa deva, necessariamente, degenerar em violência; é como se fizessem desse autor um "crítico avant la lettre da Revolução Francesa" (Bignotto, 2010, p. 56). Além disso, fica evidente que os intérpretes liberais isolam o ideal da virtude cívica do ideal de liberdade, igualmente prezado na tradição republicana, redundando erroneamente em supressão da individualidade.

Em resumo, interpretando mais rigorosamente as ideias de Montesquieu, o que se pode afirmar é que as repúblicas são efetivamente "algo raro e difícil de ser erigido" (Bignotto, 2010, p. 47), o que não implica em seu anacronismo ou sua irrelevância para a era moderna, ao contrário do que afirmam autores liberais contemporâneos ${ }^{4}$. Mais do que discutir pormenorizadamente a obra de Montesquieu, o que convém agora é enfatizar a similaridade e diferença entre seu pensamento e de Constant e dele em

\footnotetext{
${ }^{4}$ Assim, é curioso que o próprio Montesquieu apresenta elementos em diversas passagens de seu texto, $O$ espírito das leis, que desautorizam a exegese que assevera a impossibilidade da via republicana: quando trata das leis de uma democracia, fala factualmente de repúblicas democráticas (Bignotto, op.cit., p. 39); quando distingue as repúblicas democráticas das aristocráticas, tais como as existentes nas cidades italianas; quando fala das repúblicas comerciantes, como Atenas e que, por conseguinte, poderiam, a princípio, se compatibilizar com a cultura da centralidade do comércio na vida moderna; e quando sugere a possibilidade, antes mencionada das "repúblicas federativas", compensando a fraqueza da defesa do território das pequenas repúblicas, argumento bastante influente entre os republicanos norte-americanos do século XVIII.
} 
relação à retórica de Berlin e dos liberais conservadores, que modificam claramente os topos argumentativos originais ${ }^{5}$. O que se verifica, portanto, como denuncia Skinner com propriedade, é um processo de dogmatização em torno ao conceito liberal de liberdade no fim do século XX. Mais do que simplesmente repetir os argumentos dos autores do passado (Hobbes, Bentham, Constant e Montesquieu) Isaiah Berlin, bem como outros neoconservadores estão, nesse contexto de disputa ideológica, enfatizando o caráter privado e anti-estatal do conceito liberal de liberdade.

\section{Os significados neorrepublicanos de liberdade}

Reconhecendo que o republicanismo é também marcado por diversas correntes internas e que combinam de modo variado os conceitos de virtude cívica, liberdade e participação política, pode-se defini-lo do seguinte modo:

A política republicana está preocupada com a possibilidade dos cidadãos interdependentes deliberarem sobre e realizar os bens comuns a uma comunidade política em desenvolvimento, pelo menos tanto promovendo os interesses individuais quanto protegendo os direitos individuais. (Honahan, 2002, p. 1, trad. minha).

Como mostra a autora, o republicanismo distingue-se das tradições liberais e comunitaristas pela importância que confere às dimensões da liberdade, da virtude cívica e do bem comum como constructos artificiais e absolutamente relevantes para a

\footnotetext{
${ }^{5}$ Essas tópicas asseveram basicamente que no mundo moderno o ethos comercial dificulta a vivência da liberdade política plena, positiva, restando experimentá-la como não-interferência. Além disso, acrescentaria Berlin, o valor supremo do indivíduo precisa ser compatibilizado com o pluralismo de valores, horizonte inarredável dos tempos modernos, de acordo com interpretação canônica de Max Weber, o que, na sua concepção, inviabiliza a liberdade positiva, concebendo-a como a realização de todos os indivíduos pela participação política que visa um bem comum. Temos assim três passos distintos na argumentação: um que afirma que a república é anacrônica por causa da preponderância do ethos mercantil (ou porque não há consenso sobre valores, no caso de Berlin e Weber); em segundo lugar, o assentimento com a ideia de que a liberdade republicana consiste na participação ativa na política; e o terceiro, que essa liberdade redunda necessariamente em opressão aos indivíduos. Montesquieu assente apenas às duas primeiras partes da argumentação, com a ressalva da possibilidade factível de uma federação de repúblicas na era moderna; Constant, Berlin e os neoconservadores às três, com a ressalva que, ao contrário de Constant, esses últimos contestam qualquer importância da participação política.
} 
política. Todavia, o procedimento de definição do republicanismo por diferenciação das outras tradições é ele mesmo problemático. Mesmo entre aqueles que identificam essa tradição como particular e distinta das demais, não concordam sobre quais os seus valores e conceitos-chave e os pensadores nela devem estar inclusos: Maquiavel, Aristóteles, Rousseau e mesmo Locke são, por exemplo, por uns aproximados do republicanismo e por outros afastados dessa tradição. Entretanto, mais do que pensar a tradição como uma questão de descendência genética, importa ter em mente que uma tradição é por si só algo construído retrospectivamente, por aqueles que, retornando ao passado, procuram deliberadamente visões de mundo afins às suas, com vista ao entendimento do tempo presente.

Em Diálogo em torno da república, o desacordo entre os autores, Maurizio Viroli e Norberto Bobbio expressa bem a complexidade da definição e distinção entre republicanos e liberais. A interlocução entre os dois gira em torno de três questões: a distinção entre três tradições políticas (liberalismo, republicanismo e democracia), em função de três significados diferentes de liberdade; a relação entre Estado opressor e republicanismo; e a existência ou não de repúblicas e de uma tradição republicana.

Digno de nota é a correta identificação por parte de Viroli de que no centro da teoria política republicana se situa o princípio da liberdade política. Em Republicanism, o autor reitera que é a partir da tradição do republicanismo moderno, criada no fim da Idade Média nas cidades italianas, que o princípio da liberdade política é o cerne da política, de modo que suas instituições devem preservá-la (Viroli, 2002, p. 3). Não apenas o republicanismo a essa época, mas o liberalismo, que sucede a essa primeira tradição, também formula sua linguagem política a partir de uma compreensão específica sobre a liberdade, princípio este que está no centro dos processos constitutivos da era moderna, a Revolução Inglesa, Americana e Francesa.

Também importante é a diferenciação feita por Viroli entre democracia e república. Aristóteles foi quem primeiro fez mais claramente essa distinção, caracterizando a república, politeia, como um regime misto. Para ele, há basicamente três tipos de regimes políticos, distinguidos pelo número dos que governam: monarquia, aristocracia e democracia. Cada um deles pode ser apropriado em certas condições, mas todos são identificados como instáveis e inclinados à corrupção, transformando-se em, reciprocamente, tirania, oligarquia e oclocracia, o que ocorre 
quando o poder político é utilizado para atender não ao bem comum, mas a interesses particulares. A democracia é caracterizada como o governo dos "muitos", e criticada por Aristóteles pelos seus excessos, como é o caso do ostracismo utilizado para perseguir facções rivais. A politeia, ao contrário, é definida como um regime da mediania, em que a existência de elementos aristocráticos e monárquicos (Viroli, 2002, p.5; Hankins, 2010, p. 455) ajuda a conter as desmedidas por maior igualdade praticada pelo demos.

Em geral, a distinção entre república e democracia permaneceu com razoável consenso na teoria política antiga e moderna, ainda que, obviamente, os termos "república" e "democracia" tenham variado semanticamente e algumas vezes tendo sido tomados como sinônimos. Nesse sentido, podemos identificar pensadores republicanos, tais como Cícero e John Milton, mas que não são rigorosamente democratas, pois defendem muito mais uma república de feitio aristocrático do que popular, na medida em que a participação dos cidadãos comuns deve ser limitada a espaços e funções específicas. Sobre Maquiavel, por exemplo, Viroli afirma:

\footnotetext{
Republicanismo na sua versão clássica, a qual eu identifico Nicolau Maquiavel, não é uma teoria da democracia participativa, como alguns teóricos reivindicam, tendo em vista fontes mais recentes. É sim uma teoria da liberdade política que considera que a participação nas deliberações soberanas necessária para a defesa da liberdade apenas quando ela permanece com suas fronteiras bem definidas (Viroli, 2002, p. 4, trad. nossa).
}

Certamente que Viroli tem razão em dissociar a defesa de uma democracia radical do pensamento de Maquiavel. Todavia, o lugar de Maquiavel como republicano e não um democrata está longe de ser consensual. John McCormick, por exemplo, ataca frontalmente as interpretações da obra de Maquiavel, como teórico da liberdade neorromana, feitas por Viroli, Skinner e Pettit, dando especial atenção às "tendências pró-plebeias do pensador florentino, realizando um esforço para trazê-lo para o leito do radicalismo democrático contemporâneo" (Silva, 2011, p. 46). Se o esforço de McCormick ajuda a contrabalançar a leitura de Maquiavel como um pensador que entende a liberdade apenas como segurança individual, garantida pelas leis e pelo 
civismo dos cidadãos, ele parece exagerar ao atribuir anacronicamente a Maquiavel um valor, o da democracia, ausente ao contexto desse autor. Pois tanto o republicanismo quanto o liberalismo nascem como linguagens políticas reticentes à democracia, não incorporando o princípio da soberania popular ou apenas o fazendo de modo parcial. Assim, embora não estejamos em condições de discutir pormenorizadamente aqui as interpretações da obra maquiaveliana, cumpre destacar que ainda que o termo democracia fosse incomum à época do pensador florentino, fica evidente, pelas críticas que ele faz à república de Veneza, que a participação ampla do povo torna o regime mais livre e mais forte frente às ameaças externas (Bignotto, 1991, p. 102-109).

Importa reter que, na opinião de Viroli, o conceito republicano de liberdade não pressupõe necessariamente autogoverno, mas sim ausência de "vontade arbitrária de um homem ou de alguns homens". O republicanismo é muito mais uma teoria que supõe um governo representativo dotado de limites constitucionais do que uma forma de democracia marcada por intensa participação popular, diz Viroli (Bobbio, 2002, p. 6). Democratas e republicanos, por conseguinte, divergem acerca do valor da participação política: enquanto os primeiros consideram-na essencial, os teóricos do segundo tipo a entendem como um "meio de proteger a liberdade e selecionar os mais virtuosos e bem qualificados cidadãos para as posições de liderança, encorajando-os então a uma cultura política hostil à dominação" (Viroli, 2002, p. 11, trad. nossa) ${ }^{6}$. A liberdade republicana é definida como "não-dependência": um escravo que tenha como dono um senhor benevolente e que, portanto, não interfira em sua vida, ainda assim não é livre, pois vive sob sua dependência. Assim, "a dependência é uma violação mais grave à liberdade do que a interferência" (idem, ibidem, trad. minha, p. 10). Por outro lado, um governo representativo, limitado por leis válidas para todos, interfere, mas não produz dominação. Vê-se, enfim, que Viroli adota a concepção de liberdade expressa de maneira negativa (não-dominação), ainda que o autor advirta

\footnotetext{
6 Ainda que de modo impróprio, é por causa desse elemento aparentemente "aristocrático" dos cidadãos mais qualificados que McCormick afirma que os "democratas devem ficar preocupados quando os filósofos empregam a linguagem do republicanismo", pois historicamente o republicanismo "clama por golpes aristocráticos contra governos populares ou justifica a consolidação oligárquica quando regimes democráticos foram derrubados" (2011, p. 141, trad. minha). Em outro texto, esse autor afirma que o "republicanismo, em sua forma antiga e moderna de teoria e prática, garante a posição privilegiada da elites mais do que facilita a participação política do povo em geral" (2003, p. 615).
} 
que a concepção republicana de liberdade não é, segundo a terminologia de Berlin, nem positiva nem negativa: "é fácil ver que a concepção republicana de liberdade não é nem negativa nem positiva descritas por Berlin e Constant" (Viroli, 2002, p. 40, trad. nossa). Sua concepção de liberdade republicana converge com a opinião de dois importantes estudiosos dessa tradição, Quentin Skinner e Philip Pettit

Outro ponto importante mencionado no diálogo entre Viroli e Bobbio é a associação entre republicanismo e opressão estatal. Essa acusação recorrente é contestada por Viroli de dois modos: primeiro, salientando que a liberdade republicana tem, como o liberalismo (que, na sua concepção, "tomou de empréstimo" esse valor do republicanismo), a individualidade como um bem a ser protegido pelo Estado. Isso significa que o republicanismo é uma teoria adequada aos tempos atuais, na medida em que ele não postula que os indivíduos sejam coagidos a abdicar de seus negócios e interesses particulares. Em segundo lugar, associando a opressão estatal a uma apropriação equívoca do republicanismo ocorrida na matriz francesa. Segundo o autor, foi a condenação da sociedade mercantil, insistindo na primazia da vida política, que fez com que o republicanismo francês degenerasse em jacobinismo (Viroli, 2002, p. 31-33). O autor assevera que a crítica à mercantilização da vida é uma tópica do republicanismo jacobino, não do republicanismo clássico, que afirma a compatibilidade entre a busca de riquezas e de grandeza pessoal e a liberdade política.

Contra, portanto, a tese de que a república é anacrônica, Viroli argumenta que o ideário republicano contribuiu fortemente para a formação do mundo moderno

\footnotetext{
7 Uma diferença, contudo, entre eles, é que Viroli caracteriza o republicanismo clássico como uma tradição que se inicia, a rigor, com as repúblicas do Renascimento italiano, Florença, Veneza, Siena, Gênova e Luca. Para ele, teria se criado a partir dessa experiência política uma nova ciência de governo, baseado no senso de dignidade e de direitos de todos os indivíduos. Destarte, ao contrário, de Grécia e Roma, sociedades baseadas na escravidão, as repúblicas italianas conseguiram conciliar a liberdade individual com a busca por riqueza material e espiritual. Se a visão de Viroli é excessivamente idealizada no tocante a esse senso universal de dignidade (basta pensar na exclusão política das mulheres nas repúblicas da Itália, bem como das constantes disputas belicosas entre elas, de tal modo que a "grandeza" de uma república podia significar a ruína de outra) ela, de qualquer modo, marca uma forte consenso entre ele, Skinner e Pettit: a recusa em associar republicanismo a experiência da polis grega. Ao diferenciar a tradição grega da republicana, eles chamam a atenção para o fato de que os teóricos da liberdade republicana conheciam a possibilidade de que a democracia cometesse excessos, incorrendo na tirania da maioria.
} 
através das mencionadas cidades republicanas da Itália, na Holanda, na Inglaterra, na América e, especialmente, constituindo um repertório ético fundamental para o Iluminismo que, através de Voltaire, D`Alembert e Rousseau, se apropriaram dele (Viroli, 2002 p. 31). Se o autor parece ter razão quando acentua a importância histórica do republicanismo na modernidade, sua solução de dissociar a matriz francesa de uma versão mais "fidedigna" do republicanismo é claramente insatisfatória.

Passando à avaliação de outro importante teórico do "neorrepublicanismo", Quentin Skinner, importa considerar brevemente seu esforço de reconstrução do contexto discursivo na Inglaterra e a ascensão e queda da teoria neorromana de liberdade. Trata-se, para esse autor, de localizar o momento decisivo em que o liberalismo, como modelo para se pensar a liberdade política, triunfa, deixando essa teoria desacreditada.

No século XVI e XVII, os defensores da autonomia do Parlamento, frente ao poder real inglês, personificado por Carlos I, entraram em um embate ideológico intenso com os defensores do poder absoluto do rei, sobretudo Hobbes. Partindo de uma concepção materialista e determinista da realidade, esse filósofo afirma que a liberdade consiste em não ter o corpo impedido de agir de acordo com seus poderes: "quando dizemos que alguém agiu livremente, isto quer simplesmente dizer que ele realizou uma ação que tinha vontade de realizar, e o fez sem estorvo ou impedimento externo" (Skinner, 1999, p. 19). Para Hobbes, a liberdade inicia-se quando a lei silenciase.

O que Skinner demonstra habilmente é como Hobbes, apropriando-se da linguagem neorromana da liberdade, com a qual ele manteve contato em seus estudos humanistas de juventude (Skinner, 2010, cap. 1), subverteu o sentido original de liberdade civil, até então associado ao ideal clássico do Estado livre. Logo após essa retórica poderosa expressa no De Cive, mas, sobretudo, no Leviatã, vários defensores da causa parlamentar, como Marchamont Nedham, John Milton, James Harrington, entre outros, responderam publicamente a Hobbes reafirmando o entendimento clássico de liberdade. Recorrendo aos moralistas e historiadores romanos como Cícero, Tácito, Salusto, bem como aos republicanos do Renascimento italiano, em particular Maquiavel, os autores ingleses reafirmavam a associação entre liberdade a governo livre, entendendo por isso as formas radicais de governo representativo. 
Para eles, ao contrário de Hobbes, defensor da soberania absoluta, a liberdade individual e a liberdade da cidade estão necessariamente vinculadas. Haveria, segundo a teoria neorromana, duas formas para o indivíduo e a cidade perderem a liberdade. A primeira é ser coagido a agir de um modo que não está prescrito ou que é proibido por lei. O tirano que usurpa a propriedade individual é um exemplo vivo à época desse primeiro caso. Mas a liberdade não é limitada apenas pela coerção aberta. O segundo caso, já tratado na análise sobre Viroli, consiste em não sofrer alguma interferência direta, mas viver numa condição em que isso pode ocorrer; trata-se da sujeição ou dependência política. Esse é o caso contra o qual se voltavam os republicanos ingleses no século XVII: a prerrogativa real de certos poderes, como o veto sobre decisões dos parlamentares ou a criação de novos tributos sem a concomitante aprovação dos mesmos pelo Parlamento. Quando a simples vontade do rei é transformada em lei, todos os cidadãos são reduzidos à servidão.

O historiador inglês enfatiza que a liberdade civil é definida pelos republicanos romanos, pelo humanismo cívico e por Maquiavel no Renascimento italiano, e pelos defensores da autonomia do Parlamento na Inglaterra revolucionária por oposição à condição do escravo (aspecto também salientado por Viroli). Esse ponto da teoria republicana revela sua radical diferença com o liberalismo: enquanto este entende que a supressão da liberdade se dá enquanto permanece a interferência, qualquer que seja ela, de modo que, findada a interferência, volto a ser livre, para a primeira tradição a ausência de liberdade já ocorre e continua subsistindo simplesmente na ausência de direitos, ainda que não haja interferência alguma (Skinner, 2005, p. 33).

Cumpre dizer que Skinner prefere intitular de teoria neorromana e não republicana da liberdade, pois muitos teóricos a que ele faz referência não manifestavam preferência pela república. Esses revoltosos ingleses entendiam que uma monarquia limitada por leis feitas por um corpo político independente é compatível com as condições de um Estado livre. República não se opõe nessa chave de compreensão a monarquia, mas a despotismo. Nesse sentido, o uso "republicano" é na opinião de Skinner equívoco para se referir a essa escola de pensamento. Liberdade 
neorromana associa-se, na concepção do autor, não exclusivamente às repúblicas, mas a governo livre que significa fundamentalmente o governo que permite o direito a cada cidadão de "igual participação na elaboração de leis", que implica em poder "decretar e revogar leis" (Skinner, 2005, p. 35). O mesmo aspecto é salientado, por exemplo, por Renato Janine Ribeiro. Como explica, o termo "monarquia" descreve o governo de um só, ao passo que respublica não se refere ao número dos que governam, mas com que finalidade é exercido o poder: o bem comum. Sendo assim, até a Revolução Gloriosa e a emergência da matriz republicana inglesa, acreditava-se que um monarca poderia governar em função do bem comum. Segundo Hankins, havia de fato uma imprecisão conceitual acerca do significado de república: "no período prémoderno, por contraste, respublica era um termo aplicado a uma grande variedade de regimes, à realeza bem como à aristocracia e ao governo popular e mesmo à oligarquia" (2010, p. 453, trad. minha) ${ }^{8}$. Hankins, todavia, diverge parcialmente de Skinner, ao afirmar que é precisamente na Renascença italiana que o conceito de república começa a ser caraterizado em oposição à monarquia. Embora os humanistas não acreditassem que a respublica excluísse a possibilidade do governo de "um só", eles imaginavam que esse governo deveria dar origem posteriormente a um governo amplo. Mas é, sobretudo, a partir do século XVIII, com a matriz republicana francesa e a norte-americana, que o espírito antimonárquico se consolida de modo mais evidente no ideário republicano.

Em textos mais recentes, Skinner esclarece que a concepção neorromana de liberdade é negativa, como a liberal, mas distinta e superior a ela. Além da liberdade negativa (liberdade de interferência) e a positiva (pressupondo a política como realização plena da natureza humana), descritas por Berlin, haveria um terceiro tipo de liberdade: não estar sob a dependência de outrem. Tendo como origem o direito romano e medieval (em que o status do cidadão, sui iuris, é definido por oposição ao de escravo, sub potestate), os teóricos da liberdade neorromana entendem que viver sob a existência de poderes arbitrários (ainda que esses poderes não sejam efetivamente exercidos) é viver na servidão. A única forma de garantir a liberdade

\footnotetext{
${ }^{8}$ O próprio Aristóteles, principal referência grega no uso do termo politeia, que deu origem a respublica, usa o termo de modo dúbio, ora significando qualquer forma de constituição política, isto é, organização formal da política, ora como uma forma específica de constituição, o governo da virtude dos cidadãos (Hankins, 2010, p. 456).
} 
individual é uma república, o governo marcado não pela participação direta e ampliada do povo, mas pela sua participação funcional que estimule a virtude cívica e a capacidade de priorizar o interesse público em detrimento do particular; um governo das leis, em que todos, inclusive os governantes (que pode, a princípio, ser um monarca), se submetam a elas e ao bem comum.

Como observa Hankins, Skinner parece ter se distanciado de seus primeiros escritos sobre o republicanismo, inclusive abandonando essa terminologia, e se aproximando cada vez mais da posição assumida por Philip Pettit. Ao contrário do que argumenta Pocock que, em sua caracterização da tradição republicana, associa o pensamento de Maquiavel ao de Aristóteles, o republicanismo à experiência da polis, Skinner afirma que os neorromanos, inclusive Maquiavel, entendiam a liberdade somente como um status individual de salvaguarda pelas leis da dependência arbitrária. Gradualmente, Skinner estaria "distanciando" essa tradição da teoria da democracia participativa e indicando que a liberdade como não dependência é uma alternativa não somente à liberdade como não interferência, mas também como participação política. Fica, todavia, a dúvida acerca de que tipo de participação política e de civismo é necessário para a preservação da liberdade ${ }^{9}$.

Philip Pettit é, por seu turno, autor de influente obra sobre o republicanismo na teoria política contemporânea, Republicanism. Nela, ele defende que o ideal republicano de liberdade é mais bem descrito como "não dominação". Melhor do que o ideal liberal de não interferência ${ }^{10}$, complacente com diversas formas de dominação (como as sofridas pelos trabalhadores assalariados em relação a seus patrões, pelas mulheres em relação a seus maridos), a concepção de liberdade como não dominação tem duas vantagens sobre a primeira: ela permite distinguir a interferência arbitrária

\footnotetext{
${ }^{9}$ Skinner fala vagamente sobre o caráter coercitivo da lei que deve assegurar o mínimo necessário de participação e de devoção ao interesse público, necessários à liberdade Daí, mais uma vez, as leis os forçou a serem livres, coagindo-os para a defesa da sua liberdade, quando o seu instinto natural de autopreservação levaria-os à derrota e, portanto, à servidão"(Skinner, 1993, p. 306, trad. minha).

${ }^{10}$ Que a partir da Revolução Americana assume o lugar do republicanismo como pensamento político hegemônico, produzindo um "golpe de Estado" contra a liberdade republicana (Pettit, 1997, p. 50, trad. minha).
} 
(produzida por um senhor, um patrão ou um marido dominador) da interferência condizente com a liberdade, isto é, aquela provocada pelas leis promulgadas por um governo legítimo sobre os indivíduos. Diferentemente do liberalismo que pensa que quanto mais leis, menor a liberdade individual, o republicanismo assevera que as leis são essenciais para criar as condições de exercício da liberdade individual. Além disso, o ideal de não dominação obsta a existência de casos em que ainda que não haja uma interferência clara, há dominação; por meio de mecanismos institucionais (como o da representação, da rotatividade nos cargos de poder, da separação entre os poderes), o indivíduo está preservado não apenas de interferências arbitrárias, como também de viver sob a boa vontade de outrem.

Mas, como se percebe, e Pettit apressa-se em esclarecer, o ideal de nondomination não é um ideal positivo de liberdade. Diferenciando-se de uma tradição "populista", ancorada em especial na obra de Rousseau, que identifica liberdade e autogoverno, a nondomination consente quanto à importância da participação política ampliada e da democracia apenas enquanto meio de salvaguarda da liberdade, entendida como segurança individual e tranquilidade de vida. Para ele, é precisamente por não se identificar com a concepção aristotélica ou rousseauniana de liberdade que a concepção republicana de liberdade tem grande valor para a teoria política contemporânea. Uma vez que não pressupõe que a liberdade se dá pela atualização da vida pública, essa concepção é compatível com o pluralismo de valores que caracteriza a modernidade.

Percebe-se que os autores centrais no debate sobre a liberdade associados ao retorno do republicanismo, Viroli, Skinner e Pettit, se atacam o atomismo liberal e sua concepção negativa de liberdade, se mostram igualmente críticos ao que chamam de modelo neo-ateniense ou "populista" de liberdade. Contra essa tendência teórica, que define a liberdade como a realização de um fim coletivamente compartilhado, Viroli, Skinner e Pettit formulam uma concepção de liberdade que não se vincula necessariamente às formas ampliadas de democracia ${ }^{11}$.

${ }^{11}$ É verdade que entre Skinner e Pettit existem não também diferenças teóricas. Skinner, apesar de reconhecer a influência da obra do filósofo irlandês sobre si, argumenta que Pettit sugere que a liberdade republicana pode encarnar elementos negativos e positivos, ao passo que o primeiro reafirma que ela deve ser descrita em termos exclusivamente negativos (Skinner, 2005, p. 39). Pettit afirma que enquanto Skinner supõe que a liberdade deve ser entendida como não-dominação e não-interferência, 
Para além da questão da interpretação de Pettit sobre a obra de Skinner (ela mesma marcada por variações no entendimento do conceito de liberdade) e das pequenas diferenças entre eles, cumpre entender de que modo a compreensão desse conceito constitui uma alternativa à compreensão. Começando pela segunda indagação, no caso de Pettit, essa relação fica bastante evidente, pois longe de se limitar à investigação histórica, como Skinner, ele quer demonstrar a contribuição da teoria republicana da liberdade para a teoria democrática. Assim, ao contrário do historiador de Cambridge, Pettit se aventura a formular uma concepção de democracia, condizente com sua definição de liberdade, a "democracia contestatória". Em Republicanism ele esclarece que ao contrário de uma concepção de democracia assentada sobre o consenso, nesse modelo o que mais importa não é o governo fazer o que o povo determina, mas a capacidade do povo poder contestar o que os governantes fazem (Pettit, 1998, p. IX). Como nota Ricardo Silva (2011), o modelo de democracia contestatória de Pettit assevera que além do momento eleitoral, é preciso garantir canais institucionais para que o povo possa questionar as políticas adotadas, "despolitizando" a democracia, isto é, retirando dos políticos profissionais a prerrogativa de avaliação sobre elas. Se o cidadão é convocado a participar, no modelo contestatório, isto se dá claramente numa chave negativa e reativa, em que nos fóruns deliberativos e decisórios ele pode reclamar maior responsividade dos políticos a partir de decisões já adotadas. Pettit diferencia-se, por conseguinte, da ideia de democracia participativa, supondo por essa ideia uma situação de forte ativismo dos cidadãos mobilizados em prol do interesse público, contexto esse, afirma ele, impossível de se realizar na atualidade. O acento de sua concepção democrática recai no bom

de tal modo que tanto os liberais clássicos quanto os neorromanos estão preocupados em reduzir a coerção sobre o corpo e a vontade, o filósofo irlandês afirma que liberdade é simplesmente nãodominação, de tal modo que ele tem como prioridade política a redução não da interferência, como os primeiros, mas de qualquer forma de dominação. A diferença entre eles seria uma sutil ordem de prioridades: Skinner entende que dominação sem interferência e interferência sem dominação são situações equivalentes, ao passo que Pettit entende que a primeira situação é pior do que a segunda. Sobre isso ver: Silva, 2008, 2011. 
funcionamento das instituições existentes para a realização da contestação, mesma ênfase constatada nas obras de Viroli e Skinner.

Sobre a possibilidade de o republicanismo constituir um concepção alternativa de liberdade ao liberalismo, Viroli observa, muito impactado pelos escritos de Pettit, que este último logrou um assombroso sucesso em postular uma concepção de liberdade como não interferência; também foi bem sucedido em defender os indivíduos contra a interferência do Estado e de particulares, mas foi displicente com as diversas reivindicações por mais liberdade de homens e mulheres que vivem em situação de dominação, vivendo, na expressão de Pettit, com os "olhos baixos" diante de seus "senhores" (Pettit, 1998). Concordando com Viroli, podemos dizer, no entanto, que a concepção esposada por ele, Skinner e Pettit, apesar de serem importantes na demarcação do campo conceitual republicano em relação ao liberalismo, é ainda insuficiente para obstar todas as formas de dominação presentes nas democracias atuais. Para esclarecer nosso ponto de vista, nos apropriaremos da obra de outro neorrepublicano, Jean-Fabien Spitz, que apresenta críticas a esses autores, afins às por nós formuladas.

Concordando nesse aspecto com Viroli, Skinner e Pettit (1997), Spitz afirma que o pensamento liberal tornou-se hegemônico no mundo contemporâneo, deixando o conceito de liberdade órfão de um de seus pais, isto é, o republicanismo. É contra essa hegemonia liberal, portanto, que o esforço desse autor se dirige, tentando demonstrar a via republicana da liberdade.

Para Spitz, o liberalismo, iniciado em meados do século XVII e em crescente ascensão a partir daí, se organiza em torno a três princípios básicos: a neutralidade de valores do Estado (num ambiente de crescente laicização da política, com o qual contribui também a tradição republicana), os direitos invioláveis dos indivíduos e a definição jurídica de liberdade, quer dizer, a ideia de que os mecanismos constitucionais são os meios principais de garantia contra a tirania e a usurpação particular. O liberalismo, baseado na filosofia do direito, pensa o indivíduo como portador de direitos inalienáveis, pré-políticos, dando destaque para a necessidade de se garantir a estabilidade política, como condição para o gozo da liberdade privada. 0 Estado, nessa acepção, não tem uma função moralizadora, na medida em que os valores são formados privadamente, tendo ele somente que salvaguardar o 
desenvolvimento livre e autônomo dos indivíduos; esfera pública e esfera privada ficam apartadas uma da outra ${ }^{12}$.

O republicanismo, ao contrário, prioriza não a estabilidade, mas a legitimidade do poder político, entendendo os direitos dos indivíduos como dependentes da própria realização dos fins comuns à sociedade. É através da política e do Estado que o cidadão e sua moralidade se formam intersubjetivamente com os seus concidadãos, não a despeito deles; a política assume, portanto, um fim ético: a criação coletiva da sociabilidade e da liberdade.

Contra a linguagem liberal, o republicanismo denuncia o ceticismo moral liberal, que supondo uma posição neutra acaba por naturalizar uma ética individualista e utilitária, em que a persecução dos interesses privados, em detrimento do interesse público, assume ares de inevitabilidade. Além disso, a tradição republicana se propõe a pensar a ordem política justa e igualitária como formadora dos direitos e dos deveres individuais, rompendo com a lógica naturalista e pré-política do liberalismo. Numa absoluta reciprocidade de direitos e deveres, a tradição republicana pensa a lei como oriunda da própria coletividade que deve obedecê-la não apenas em função da coerção da lei, mas pela legitimidade de seu fundamento; por fim, contesta a concepção negativa de liberdade, entendendo-a como uma perda de liberdade em que o cidadão se distancia da política, se tornando incapaz de determinar seu próprio destino.

Contra a dogmatização do princípio do politeísmo de valores (expresso paradigmaticamente por Weber e retomado por Berlin), Spitz destaca os impasses produzidos pelo liberalismo ao polarizar as esferas privada e pública, a vida do indivíduo da do cidadão. Mais o autor vai além: ele critica também as formulações neorrepublicanas que apesar de repudiarem a princípio a concepção liberal,

\footnotetext{
12 Embora Spitz não atente para este aspecto, o liberalismo ético inglês do século XIX, de John Stuart Mill e T.H. Green, por exemplo, considerava o Estado como um agente ético, mas essa corrente liberal encontrava séries dificuldades em conciliar um sentido mais privado de liberdade, como desenvolvimento moral diferenciado e autônomo, com a função paternalista do Estado, necessária para garantir as condições desse mesmo desenvolvimento (Bellamy, 1994).
} 
aproximam-se dela ao negar sua relação com a tradição da democracia. Além de questionável do ponto de vista histórico e interpretativo, tal esforço faz do republicanismo refém dos mesmos problemas da teoria liberal, como, por exemplo, da rígida separação entre a esfera pública e privada, ponto frequentemente revisitado pelas feministas denunciando a miopia da teoria política clássica para a dominação de gênero (Pateman, 1993).

Ademais, alerta Spitz, não é possível compatibilizar o elogio da participação política e virtude cívica, mesmo que apenas instrumentalmente, com uma concepção negativa da liberdade; os neorrepublicanos, como os liberais, naturalizam a liberdade como independência individual ou como status de segurança, e não justificam racionalmente a legitimidade desse ideal, não percebendo que tal assentimento entra em contradição com o axioma do politeísmo de valores. Como postular a necessidade universal da primazia do interesse público e ao mesmo tempo o pluralismo moral?

Julga-se que a principal contribuição de Spitz ao debate sobre a liberdade é a sua ênfase sobre a dimensão inerentemente moral da política. Isso significa que uma concepção de liberdade dissociada de qualquer quadro de valores, configura uma contradição em termos. Contra uma concepção jurídica de liberdade, supostamente neutra, e contra uma leitura do republicanismo como uma tradição também negativa da liberdade (entendendo esta como um status de segurança garantido pelas instituições), o livro La liberté politique apresenta uma nova visão sobre a tradição republicana, recusando as dicotomias presentes no debate sobre a liberdade (liberdade dos antigos versus dos modernos, negativa versus positiva) ressaltando a riqueza dessa tradição para pensar a política contemporânea fora dos parâmetros e dos impasses da linguagem liberal.

A aposta institucionalista de Pettit e de seus pares mostra-se frágil e precária à luz da própria tradição republicana na qual ele se baseia. A expectativa de eliminar as variadas formas de dominação de uma sociedade, fortalecendo os direitos individuais, sem a contrapartida de ampliar o espaço de participação e deliberação pública é insuficiente. 


\section{Neorrepublicanismo e democracia: um novo modelo?}

Uma útil diferenciação entre as diversas formas contemporâneas de apropriação da tradição republicana na atualidade é feita por Honahan (2005). A autora afirma que os autores neorrepublicanos, em geral, dão bastante destaque às ideias de liberdade, virtude cívica, participação política e reconhecimento, de maneira diversificada. Todavia, é possível diferenciar duas formas gerais de se apropriar desse estoque conceitual: a do republicanismo instrumental, que entende o exercício ativo da cidadania como meio de garantir da liberdade individual e menos como uma atividade intrinsicamente importante; e a do republicanismo forte que salienta a importância da participação no autogoverno e na realização do bem comum. Três dos autores aqui discutidos, Viroli, Skinner e Pettit aproximam-se mais da descrição do "republicanismo instrumental". Os três se esforçam para destacar a "superioridade" do conceito republicano de liberdade, em relação ao liberalismo, mas ao mesmo tempo aproximam esse conceito dessa última tradição, como um conceito compatível com os ideais do indivíduo e do pluralismo de valores. Todos eles diferenciam a tradição republicana de uma democracia participativa ou "populista" e fundamentam sua concepção democrática num arcabouço institucional, mais do que na participação dos cidadãos na vida pública. Spitz, por sua vez, pode a princípio ser compreendido à luz do que a autora chama de "republicanismo forte", aproximando essa tradição não do liberalismo, mas da democracia, demonstrando ser necessário e possível compatibilizar o conceito de liberdade individual (e, portanto, assumir como horizonte o pluralismo de valores), com o de liberdade como autogoverno.

Se, com efeito, as abordagens de Viroli, Skinner e Pettit constituem momentos importantes de crítica ao liberalismo, ainda não são suficientes para formular um conceito coerente de liberdade que seja, de fato, distinto do conceito liberal e que consiga incorporar as diversas reivindicações de emancipação, justiça, reconhecimento e maior igualdade, próprias às democracias hodiernas. Resumindo, as deficiências desse conceito decorrem: 1) do assentimento acrítico da ideia de pluralismo moral, 
impedindo dogmaticamente pensar a construção democrática de interesses públicos, o que os republicanos de outrora entendiam por "bem comum"; 2) do distanciamento da tradição democrática, caracterizada pejorativamente de "populista" e entendida sob a chave berliana de "liberdade positiva"; 3) da incorporação de uma visão atomista da sociedade em detrimento de suas relações com outros cidadãos. A obra de Spitz, por outro lado, é importante porque indica os pontos de contato e tensão entre essas linguagens da política, republicanismo e liberalismo. Por outro lado, também na obra desse autor não se encontra uma concepção ou teorização sistemática da democracia, nem parece ser essa a intenção fundamental deste autor.

Em resumo, a crítica neorrepublicana à "democracia liberal", nas suas diversas formas e defesas, se enriquece o debate da teoria democrática contemporânea, recuperando novos entendimentos sobre a liberdade e as ameaças a ela, nem sempre evidentes, ainda não conseguiu lograr uma formulação coerente e clara de um novo modelo de democracia para a atualidade.

\section{Referências bibliográficas}

Bevir, Mark. 2008. A lógica da história das ideias. Bauru, SP: Edusc.

Bellamy, Richard. 1994. Liberalismo e sociedade moderna. São Paulo: Unesp.

Berlin, Isaiah. 1981. Quatro ensaios sobre a liberdade. Brasília: Ed. UNB.

Bignotto, Newton. 1991. Maquiavel republicano. São Paulo: Loyola.

Bignotto, Newton. 2001. Origens do republicanismo moderno. Belo Horizonte: Ed. UFMG.

Bignotto, Newton. 2003. República dos antigos, república dos modernos. In: Revista USP, São Paulo, n.59, p. 36-45.

Bignotto, Newton. 2010. As aventuras da virtude: as ideias republicanas na França do século XVIII. São Paulo: Cia das Letras.

Bignotto, Newton. (org.). 2013. Matrizes do republicanismo. Belo Horizonte: Ed. UFMG.

Bobbio, Norberto e VIROLI, Maurizio. 2002. Diálogo em torno da república: os grandes temas da política e da cidadania. Rio de Janeiro: Campus.

Connell, William. 2003. The republican idea. In: Hankins, James (Ed.). Rennaissance humanism civic: reappraisals and reflections. Cambride: Cambridge University Press, p. 153-193. 
Constant, Benjamin. 1997. De la liberté des anciens comparée à celle des modernes (Discours prononcé à l'Athénée royal de Paris en 1819). In: Écrits politiques. Paris: Ed. Gallimard, p. 589619.

Guerra, Roberto. 1998. El liberalismo conservador contemporáneo. Universidad de la Laguna.

Guimarães, Juarez. s/ data. A liberdade de expressão a instituição do cidadão, 65 p.

Hankins, James. 2003. Introduction. In: Hankins, James (Ed.). Rennaissance humanism civic: reappraisals and reflections. Cambride: Cambridge University Press, p. 1-13.

Hankins, James. 2010. Exclusivist republicanism and the non-monarchical republic. In: Political Theory, 38, p.452-482.

Honahan, Iseult. 2002. Civic Republicanism. London: Routledge.

Honahan, Iseult. 2005. Enfoques republicanos contemporáneos sobre la democracia y su potencial cosmopolita. In: Isegoría, 33, p. 161-174.

Mccormick, John. 2003. Machiavelli against republicanism: on the Cambridge School's "Guicciardinian moment". In: Political Theory, vol. 31, n. 5, 2003, p. 615-643.

Mccormick, John. 2011. Machiavellian democracy. Cambridge: Cambridge University Press.

Miguel, Luís F. 2005. Teoria democrática atual: esboço de mapeamento. In: Revista Brasileira de Informação Bibliográfica em Ciências Sociais, São Paulo, n. 59, p. 5-42.

Pancera, Gabriel. 2010. Maquiavel entre repúblicas. Belo Horizonte: Ed. UFMG.

Pateman, Carole. 1992. Participação e teoria democrática. Rio de Janeiro: Paz e Terra.

Pateman, Carole. 1993. O contrato sexual. Rio de Janeiro: Paz e Terra.

Pettit, Philip. 1998. Republicanism: theory of freedom. 2a ed. Oxford: Oxford University Press.

Silva, Ricardo. 2008. Liberdade e lei no neo-republicanismo de Skinner e Pettit. In: Lua Nova, São Paulo, 7, p. 151-194.

Silva, Ricardo. 2011. Republicanismo neo-romano e democracia contestatória. Revista Sociologia e Política, v. 19, n. 39, p. 35-51.

Skinner, Quentin. 1993. The republican ideal of liberty. In: Bock, Gisela; Skinner, Quentin; Viroli, Maurizio. Machiavelli and republicanism. Cambridge: Cambridge University Press, p. 293-309.

Viroli, Maurizio. 1999. Liberdade antes do liberalismo. São Paulo: Ed. da Unesp.

Viroli, Maurizio. 2005. La libertad de las repúblicas: un tercer concepto de libertad? In: Isegoría, 33, p. 19-49.

Viroli, Maurizio. 2010. Hobbes e a liberdade republicana. São Paulo: Ed. da Unesp. 
Spitz, Jean-F. 1995. Liberté politique: essai de généalogie conceptuelle. Paris: Presse Universitaires de France.

Viroli, Maurizio. 2002. Republicanism. New York: Hill and Hang.

Vita, Álvaro de. 2011. Liberalismo, justiça social e responsabilidade individual. In: Revista Dados, vol. 54, nº 4, p. 569-608.

Waldron, Jeremy. 2012. Os fundamentos teóricos do liberalismo. Revista Leviathan, $\mathrm{n}^{\circ} 5, \mathrm{p}$. 102-132.

\begin{abstract}
Democracy and Republic: dissent on freedom and the modern languages of politics

This paper discusses the relationship between democracy and republic. The analysis begins with a discussion of the concept of freedom in the late twentieth century, characterized by advancement of conservative liberalism and, as a reaction to it, the recovery of the political tradition of republicanism. Far from being a mere disagreement between scholars, the contest between these founding languages of the modern era, indicates the debate was a factor that defines the functions of the state and democracy. The concept of freedom of the authors of republicanism, all antagonists, in some measure, of liberalism and proponents of an alternative vision of freedom is then appraised. Although the neorepublicanism doesn't have a finished conception of democracy, it allows us to formulate an integrated overview of their main problems, by the north to the elimination of all obstacles to freedom.
\end{abstract}

Key-words: Neo republicanism; Liberalism; Democracy; Freedom.

Tramitação do artigo na revista

Submetido: 04/09/2012

Revisões requeridas: 19/12/2012

Versão revista: 01/09/2013

Aceito: 01/10/2013 